\title{
Assessment of survival of patients with metastatic clear cell renal cell carcinoma after radical cytoreductive nephrectomy versus no surgery: a SEER analysis
}

\author{
Wen-Jun Xiao 1,2, Yao Zhu 1,2, Bo Dai 1,2, Hai-Liang Zhang ${ }^{1,2}$, Ding-Wei Ye ${ }^{1,2}$ \\ ${ }^{1}$ Department of Urology, Fudan University Shanghai Cancer Centre, Shanghai, People's Republic of \\ China; ${ }^{2}$ Department of Oncology, Shanghai Medical College, Fudan University, Shanghai, People's \\ Republic of China
}

\section{ABSTRACT}

Purposes: To examine the factors related to the choice of cytoreductive nephrectomy (CN) for patients with metastatic clear cell renal cell carcinoma (mCCRCC), and compare the population-based survival rates of patients treated with or without surgery in the modern targeted therapy era.

Materials and Methods: From 2006 to 2009, patients with mCCRCC were identified from SEER database. The factors that affected patients to be submitted to $\mathrm{CN}$ were examined and propensity scores for each patient were calculated. Then patients were matched based upon propensity scores. Univariable and multivariable cox regression models were used to compare survival rates of patients treated with or without surgery. Finally, sensitivity analysis for the cox model on a hazard ratio scale was performed. Results: Age, race, tumor size, $\mathrm{T}$ stage and $\mathrm{N}$ stage were associated with nephrectomy univariablely. After the match based upon propensity scores, the 1-, 2-, and 3-year cancer-specific survival rate estimates were 45.1\%, 27.9\%, and 21.7\% for the no-surgery group vs $70.6 \%, 52.2 \%$, and $41.7 \%$ for the surgery group, respectively (hazard ratio 0.42, 95\%CI: $0.35-0.52$, log-rank $\mathrm{P}<0.001)$. In multivariable Cox proportional hazard regression model, race, $\mathrm{T}$ stage, $\mathrm{N}$ stage and median household income were significantly associated with survival. Sensitivity analysis on a hazard ratio scale indicated that the hazard ratio might be above 1.00 only when the unknown factor had an opposite effect on survival which was 3-fold than $\mathrm{CN}$.

Conclusion: The results of our study showed that CN significantly improves the survival of patients with metastatic CCRCC even in the targeted therapy era.

\section{ARTICLE INFO}

\section{Key words:}

Carcinoma, Renal Cell; Nephrectomy; SEER Program; Propensity Score; Molecular

Targeted Therapy

Int Braz J Urol. 2015; 41: 288-95

Submitted for publication: November 02, 2013

Accepted after revision: June 06, 2014

\section{INTRODUCTION}

Renal cell carcinoma (RCC) is a common malignancy, and represents more than 3\% of adult solid malignant tumors (1). Most RCCs are diagnosed in early-stage disease, but approximately $25 \%$ of RCC patients have systemic metastases at initial diagnosis $(2,3)$. Two randomi- zed controlled trials have confirmed the benefit of cytoreductive nephrectomy (CN) on metastatic RCC (mRCC) in the pretargeted therapy era (4-6). The use of CN had been steadily increasing after 2001, and was generally viewed as a treatment standard $(7,8)$. In 2005, the Food and Drug Administration (FDA) approved the use of vascular endothelial growth factor receptor 
tyrosine kinase inhibitors (VEGFR-TKIs) in renal carcinoma. The unprecedented antitumor activity and relatively favorable toxicity profile of the modern targeted therapies resulted in a shift of the standard systemic therapy for mRCC (9-11). So, in the era of VEGFR-TKIs, it is uncertain the appropriate role of $\mathrm{CN}$. The present study will explore factors associated with $\mathrm{CN}$ and evaluate its role in modern day practice within a large North American population-based dataset.

\section{MATERIALSN AND METHODS}

Data for the current analysis were derived from the Surveillance, Epidemiology, and End Results (SEER) registry. The SEER has collected clinical and pathological data in 19 specified geographic areas of the United States (US) since 1973, including the Atlanta, Detroit, San Francisco-Oakland, Seattle-Puget Sound metropolitan areas and the states of Connecticut, Hawaii, Iowa, New Mexico, and Utah. These data are highly representative of the demographic makeup of the United States, especially in terms of geography, socioeconomic status, race/ethnicity, and age (12).

Because VEGFR-TKIs were mainly used for clear cell renal cell cancer (13), its diagnostic codes ("International Classification of Disease for Oncology”, 3rd edition, histology coding 8310) were used as inclusion criteria. The presence of histology coding 8310 and AJCC stage M1 (derived AJCC $6^{\text {th }}$ edition) resulted in the identification of 2305 patients with metastatic clear cell renal cell cancer (mCCRCC) from 2006 to 2009. Patients who underwent a radical surgical removal of kidney, were included in the surgery group. Only patients who did not undergo surgery were included in the "no surgery group". The duration of survival after nephrectomy or from the date of mRCC diagnosis was determined according to the SEER survival time definition. We selected 2006 as the initial year because 2005 was the time of initial regulatory approval for VEGFR-TKI's use in renal carcinoma. Follow-up was defined as the time between date of diagnosis and date of death or November 2011 whichever came first.

\section{Statistical analyses}

Baseline statistics were analyzed with means for continuous variables (age, tumor size) and proportions for categorical variables (race/ethnicity, stage). The baseline differences of two groups were compared using chi-squared for categorical variables. T-test was used for comparison of age, while Wilcoxon test was used for comparison of tumor size. Cox proportional hazard regression model was used to calculate the survival rate.

As patients were not randomly selected for nephrectomy, a propensity score was calculated reflecting the probability of a person undergoing nephrectomy given a set of known covariates. A multivariable regression model, including these factors univariably associated with nephrectomy, was used to obtain the propensity of nephrectomy for each patient. Then the patients without surgery were matched by the patients with surgery based upon the propensity score. This would adjust the bias due to imbalance of certain prognostic variables associated with nephrectomy to a certain extent. Then a cox survival model for the matched patients, including all variables associated with survival, was made to evaluate the beneficial effect of nephrectomy. Sensitivity analysis for this model on a hazard ratio scale was also performed (14). Analyses were conducted using the $\mathrm{R}$ statistical package (the $\mathrm{R}$ foundation for Statistical Computing, version 2.15.2).

\section{RESULTS}

The radical nephrectomy rate of all 2305 patients was 49.3\% ( $\mathrm{n}=1133) .943$ patients did not receive any therapy for the local tumor, while 11 patients had no information whether they received the therapy or not. 218 patients receiving other therapy rather than "radical nephrectomy" were excluded, including local tumor destruction, thermal ablation, electrocautery, cryosurgery, "simple nephrectomy" and so on. Additional exclusions consisted of unknown T stage ( $n=363)$, unknown $\mathrm{N}$ stage $(n=170)$. Only the records of patients with the tumor size available were considered in the present study. This resulted in the exclusion of another 38 patients with an unknown tumor size. So, 1505 patients were included in this study. 
Among 1505 assessable patients, 1038 (68.97\%) were men, and the average age was 62.1 years. The no-surgery patients $(\mathrm{n}=460)$ were significantly older (65.77 vs 60.51 years, $\mathrm{P}<0.001)$, had almost the same proportion of women $(31.1 \%$ vs $31.0 \%, \mathrm{P}>0.5$ ), and had smaller tumors (median size, 7.5 vs $9.0 \mathrm{~cm}, \mathrm{P}<0.001)$ than the surgery pa- tients $(\mathrm{n}=1045)$. Race, $\mathrm{T}$ stage and N stage were also associated with nephrectomy (Table-1). At 1,2 and 3 years of follow-up, the cancer-specific survival rate was $44.9 \%, 28.3 \%$, and $20.6 \%$ for the no-surgery group vs $72.7 \%, 54.1 \%$ and $47.2 \%$ for the surgery group, respectively (hazard ratio 0.39, 95\%CI: 0.33-0.46, log-rank $\mathrm{P}<0.001$ ).

Table 1 - Uni- and multivariable regression models to estimate factors associated with nephrectomy.

\begin{tabular}{|c|c|c|c|c|}
\hline & $\begin{array}{l}\text { Nephrectomy } \\
\quad N(\%)\end{array}$ & $\begin{array}{c}\text { No nephrectomy } \\
\qquad N(\%)\end{array}$ & $\begin{array}{l}\text { Univariable } \\
\text { OR (95\% Cl) }\end{array}$ & $\begin{array}{l}\text { Multivariable } \\
\text { OR }(95 \% \mathrm{CI})\end{array}$ \\
\hline N & 1045 & 460 & & \\
\hline \multicolumn{5}{|l|}{ Gender } \\
\hline Male $^{\mathrm{b}}$ & $721(69.5)$ & $317(30.5)$ & & \\
\hline Female & $324(69.4)$ & $143(30.6)$ & $1.00(0.79-1.28)$ & \\
\hline Age at diagnosis (per year increase) & & & $0.96(0.95-0.97)$ & $0.96(0.95-0.97)$ \\
\hline \multicolumn{5}{|l|}{ Race } \\
\hline Black & $47(47.0)$ & $53(53.0)$ & & \\
\hline White & $924(70.9)$ & $380(29.1)$ & $2.74(1.82-4.13)$ & $3.03(1.91-4.80)$ \\
\hline Yellow or Unknown & $74(73.2)$ & $27(26.7)$ & $3.09(1.71-5.58)$ & $3.68(1.90-7.10)$ \\
\hline Tumor size & & & $\begin{array}{c}1.0055(1.0025- \\
1.0086)\end{array}$ & $0.9997(0.997-1.002)$ \\
\hline \multicolumn{5}{|l|}{ T stage } \\
\hline T1a & $48(48.0)$ & $52(52.0)$ & & \\
\hline $\mathrm{T} 1 \mathrm{~b}$ & $111(52.1)$ & $102(47.9)$ & $1.18(0.73-1.9)$ & $1.14(0.69-1.89)$ \\
\hline T2 & $175(62.1)$ & $107(37.9)$ & $1.77(1.12-2.81)$ & $1.60(0.95-2.70)$ \\
\hline ТЗа & $260(86.7)$ & $40(13.3)$ & $7.04(4.21-11.78)$ & $7.63(4.32-13.47)$ \\
\hline T3b & $363(83.3)$ & $73(16.7)$ & $5.39(3.38-8.58)$ & $5.87(3.46-9.98)$ \\
\hline T3c & $25(73.5)$ & $9(26.5)$ & $3.01(1.28-7.09)$ & $3.10(1.24-7.75)$ \\
\hline T4 & $63(45.0)$ & $77(55.0)$ & $0.89(0.53-1.48)$ & $0.92(0.52-1.65)$ \\
\hline \multicolumn{5}{|l|}{ N stage } \\
\hline NO & $787(71.5)$ & $314(28.5)$ & & \\
\hline N1 & $156(63.2)$ & $91(36.8)$ & $0.68(0.51-0.91)$ & $0.46(0.33-0.64)$ \\
\hline N2 & $102(65.0)$ & $55(35.0)$ & $0.74(0.52-1.05)$ & $0.51(0.34-0.77)$ \\
\hline $\begin{array}{l}\text { Median household income (in tens) } \\
2000\end{array}$ & & & $1(0.9999-1.0001)$ & \\
\hline \% Unemployed 2000 & & & $\begin{array}{c}0.9998 \\
(0.9993,1.0003)\end{array}$ & \\
\hline
\end{tabular}

$\mathbf{O R}=$ odds ratio; $\mathbf{C l}$ = confidential interval 
All factors univariably associated with nephrectomy were included in the multivariable logistic regression model which is presented in Table-1. Race, $\mathrm{T}$ stage, $\mathrm{N}$ stage and age at diagnosis remained significantly associated with nephrectomy. This multivariable model was also used to estimate the propensity score for each patient (the probability of undergoing a nephrectomy).

After the match process based upon propensity scores, 442 no-surgery patients were matched with 442 surgery patients. In this matched population $(\mathrm{n}=884)$, the $1-, 2-$, and 3-year estimate was $45.1 \%, 27.9 \%$, and $21.7 \%$ for the no-surgery group vs 70.6\%, 52.2\%, and 41.7\% for the surgery group, respectively (hazard ratio 0.42 , 95\%CI: 0.35-0.52, log-rank $\mathrm{P}<0.001$, Figure-1).

\section{Figure 1 - Surgery group.}

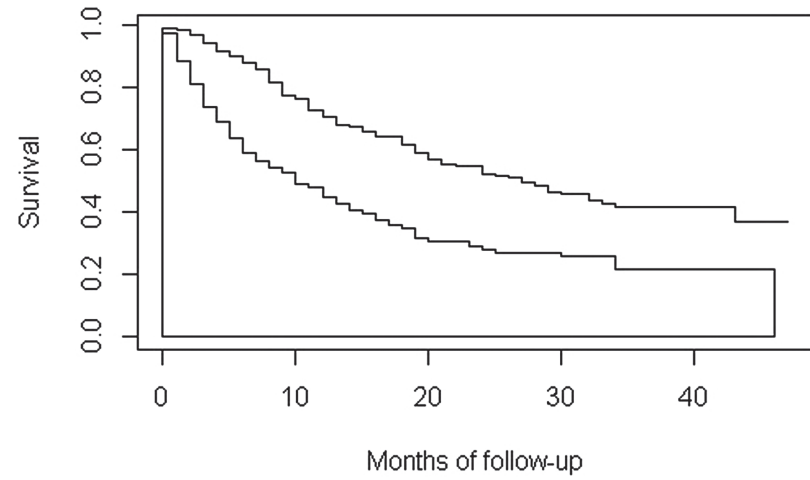

In Table-2 the results of the univariable and multivariable Cox proportional hazard regression analyses are presented. Race, tumor size, T stage, $\mathrm{N}$ stage and age at diagnosis were univariablely associated with cancer-specific survival. Less median household income associated with better cancer-specific survival, although this was not statistically significant $(\mathrm{P}=0.056)$. In multivariable Cox proportional hazard regression model, race, $\mathrm{T}$ stage, $\mathrm{N}$ stage, and median household income significantly associated with survival.

Sensitivity analysis on a hazard ratio scale indicated that the hazard ratio might be above 1.00 only when the unknown factor had an opposite effect on survival which was 3-fold than cytoreductive nephrectomy (Table-3).

\section{DISCUSSION}

As we know, the use of $\mathrm{CN}$ in the cytokine therapy era was supported by two randomized trials conducted by the Southwest Oncology Group and by the European Organization for Research and Treatment of Cancer (4-6). In the era of molecular targeted therapy, there has been some retrospective data about the combined use of $\mathrm{CN}$ with systemic targeted therapy (15-17). But their results were controversial and the number of patients was small. The present population-based study may be one of the large sample investigations to explore the prognostic factors associated with $\mathrm{CN}$ and evaluate its role in modern molecular targeted therapy era.

Among demographic variables, age and race except gender appeared to be independent factors associated with nephrectomy. Black people appeared less likely to be submitted to CN than White or Asian group, while older people were less likely, either. But these factors may be confounded by performance status, comorbidity, economic conditions and so on. Kader et al. (18) found that the prognosis amongst elderly is comparable to the younger patients if they survive the surgery. So age alone should not be a criterion whether or not to treat patients with cytoreductive surgery (8).

Tumor size and TNM stage were significantly associated with the probability of nephrectomy as well. Local or regional advanced tumors make surgical intervention a high risk and have been shown to be associated with a poor prognosis $(19,20)$. However, the majority of these patients in the present study were still submitted to $\mathrm{CN}$ : more than $70 \%$ of patients with T3 disease and more than $60 \%$ of patients with positive lymph node. This indicated the importance of surgical removal of primary tumor, tumor thrombus and positive lymph node in the mRCC setting. As T1a were concerned, more than half of these patients included in our study did not receive any therapy for renal carcinoma. However, this did not mean that the local treatment was unimportant. Due to smaller tumors, these patients might choose other local therapy rather than "radical nephrectomy", including local tumor destruction, thermal ablation, electrocautery, 
Table 2 - Cox Proportional Hazards regression analyses including nephrectomy, propensity score and other prognostic variables.

\begin{tabular}{|c|c|c|}
\hline & $\begin{array}{l}\text { Univariable HR } \\
\qquad(95 \% \mathrm{Cl})\end{array}$ & $\begin{array}{l}\text { Multivariable HR } \\
\qquad(95 \% \mathrm{Cl})\end{array}$ \\
\hline \multicolumn{3}{|l|}{ Nephrectomy } \\
\hline \multicolumn{3}{|l|}{ No } \\
\hline Yes & $0.424(0.347-0.519)$ & $0.42(0.34-0.52)$ \\
\hline \multicolumn{3}{|l|}{ Gender } \\
\hline \multicolumn{3}{|l|}{ Female } \\
\hline Male & $0.86(0.70-1.06)$ & \\
\hline Age at diagnosis (per year increase) & $1.009(1.001-1.018)$ & $1.01(0.999-1.017)$ \\
\hline \multicolumn{3}{|l|}{ Race } \\
\hline \multicolumn{3}{|l|}{ Black } \\
\hline White & $0.60(0.42-0.87)$ & $0.58(0.40-0.85)$ \\
\hline Yellow or Unknown & $0.57(0.35-0.93)$ & $0.61(0.37-1.01)$ \\
\hline Tumor size & $1.002(1.000-1.003)$ & $1.0013(0.9997-1.0028)$ \\
\hline \multicolumn{3}{|l|}{ T stage } \\
\hline \multicolumn{3}{|l|}{ T1a } \\
\hline $\mathrm{T} 1 \mathrm{~b}$ & $1.50(0.93-2.43)$ & $1.69(1.04-2.75)$ \\
\hline $\mathrm{T} 2$ & $2.00(1.26-3.16)$ & $2.17(1.35-3.53)$ \\
\hline Т3a & $1.37(0.85-2.21)$ & $1.87(1.13-3.10)$ \\
\hline T3b & $1.76(1.11-2.78)$ & $2.11(1.30-3.45)$ \\
\hline T3c & $2.07(1.07-4.03)$ & $2.05(1.03-4.08)$ \\
\hline T4 & $2.40(1.49-3.87)$ & $2.13(1.30-3.51)$ \\
\hline \multicolumn{3}{|l|}{ N stage } \\
\hline \multicolumn{3}{|l|}{ NO } \\
\hline N1 & $2.20(1.73-2.80)$ & $1.98(1.54-2.55)$ \\
\hline N2 & $3.22(2.43-4.26)$ & $3.09(2.31-4.12)$ \\
\hline Median household income (in tens) 2000 & 0.9999(0.9998-1.0000) & $0.9999(0.9998-1.0000)$ \\
\hline \% Unemployed 2000 & $1.0000(0.9998-1.001)$ & \\
\hline
\end{tabular}

$\mathbf{H R}=$ hazard ratio; $\mathbf{C l}=$ confidential interval

cryosurgery and so on. These cases were beyond the scope of the present study and have been excluded, which might result in the low proportion of patients receiving $\mathrm{CN}$.

Our results have demonstrated a survival benefit when $\mathrm{CN}$ was performed compared with no surgery. The effect of performing $\mathrm{CN}$ was related to 2.5-fold increase in cancer-specific sur- vival rate $(\mathrm{P}<0.001)$. The lack of randomization represents a major limitation of the present study, which means differences that could exist between the surgery group and no-surgery groups might not have been optimally adjusted. So propensity scores were used for statistical adjustment of some factors (age, gender, tumor size, race, TNM stage, local economic situation and so on). As 
Table 3 - Sensitivity analysis on cytoreductive nephrectomy on a Hazard Ratio scale.

\begin{tabular}{|c|c|c|c|c|}
\hline P0 & 0.2 & 0.4 & 0.6 & 0.8 \\
\hline \multicolumn{5}{|l|}{ Gamma=1.5 } \\
\hline \multicolumn{5}{|l|}{ P1 } \\
\hline 0.1 & $0.432(0.350-0.533)$ & $0.472(0.382-0.450)$ & $0.511(0.414-0.630)$ & $0.550(0.446-0.679)$ \\
\hline 0.2 & $0.413(0.334-0.509)$ & $0.450(0.365-0.555)$ & $0.488(0.395-0.602)$ & $0.525(0.426-0.648)$ \\
\hline \multicolumn{5}{|l|}{ Gamma=2 } \\
\hline \multicolumn{5}{|l|}{ P1 } \\
\hline 0.1 & $0.450(0.365-0.555)$ & $0.525(0.426-0.648)$ & $0.600(0.486-0.740)$ & $0.675(0.547-0.833)$ \\
\hline 0.2 & $0.413(0.334-0.509)$ & $0.481(0.390-0.594)$ & $0.550(0.446-0.679)$ & $0.619(0.502-0.764)$ \\
\hline \multicolumn{5}{|l|}{ Gamma=2.5 } \\
\hline \multicolumn{5}{|l|}{ P1 } \\
\hline 0.1 & $0.466(0.378-0.575)$ & $0.574(0.465-0.708)$ & $0.682(0.553-0.841)$ & $0.789(0.640-0.974)$ \\
\hline 0.2 & $0.413(0.334-0.509)$ & $0.508(0.412-0.627)$ & $0.603(0.489-0.744)$ & $0.698(0.566-0.861)$ \\
\hline \multicolumn{5}{|l|}{ Gamma=3 } \\
\hline \multicolumn{5}{|l|}{ P1 } \\
\hline 0.1 & $0.481(0.390-0.594)$ & $0.619(0.502-0.764)$ & $0.756(0.613-0.933)$ & $0.894(0.725-1.103)$ \\
\hline 0.2 & $0.413(0.334-0.509)$ & $0.530(0.430-0.655)$ & $0.648(0.526-0.800)$ & $0.766(0.621-0.945)$ \\
\hline
\end{tabular}

an observational study, other factors unavailable from SEER database may affect the survival rates of the patients with mRCC, including comorbidities, performance status, the number of metastatic sites and laboratory variables (eg, hemoglobin, calcium, lactate dehydrogenase) (21, 22). If these unmeasured variables were included in the analysis it would possibly change the conclusions. Sensitivity analysis is a way to see how much of a relationship needs to exist with the unmeasured variable before the conclusions change. In present study, the sensitivity analysis demonstrated the hazard ratio might be above 1.00 only when the unknown factor had an opposite effect on survival which was 3-fold than cytoreductive nephrectomy. So we could say that the survival benefit related to cytoreductive nephrectomy was not due to an unfavorable performance status or multiple comorbidities in the patients in the no-surgery group, and the lack of performance status and/or baseline comorbidity data did not spuriously inflate the survival benefit of surgery (23).

\section{CONCLUSIONS}

Although the data came from the United States and there might be different clinical selection criteria used for cytoreductive nephrectomy candidates in other countries, the results of our study have shown that cytoreductive nephrectomy significantly improves the survival of patients with metastatic clear cell renal cell carcinoma even in the targeted therapy era. According to SEER database, race, $\mathrm{T}$ stage, $\mathrm{N}$ stage and age at diagnosis were significantly associated with nephrectomy, while race, $\mathrm{T}$ stage, $\mathrm{N}$ stage and median household income were significantly associated with cancer-specific survival. We hope that our result sheds some light on the ongoing clinical trial of this aspect (24).

\section{ACKNOWLEDGEMENTS}

This work was supported by National $\mathrm{Na}-$ tural Science Foundation of China (grant number 81001131).

Wen-Jun Xiao, Yao Zhu contributed equally to this work. 


\section{REFERENCES}

1. Jemal A, Bray F, Center MM, Ferlay J, Ward E, Forman D. Global cancer statistics. CA Cancer J Clin. 2011; 61: 69-90. Erratum in: CA Cancer J Clin. 2011;61:134.

2. Hollingsworth JM, Miller DC, Daignault S, Hollenbeck BK. Five-year survival after surgical treatment for kidney cancer: a population-based competing risk analysis. Cancer. 2007; 109: 1763-8.

3. Chow WH, Devesa SS. Contemporary epidemiology of renal cell cancer. Cancer J. 2008; 14: 288-301.

4. Mickisch GH, Garin A, van Poppel H, de Prijck L, Sylvester $\mathrm{R}$; European Organisation for Research and Treatment of Cancer (EORTC) Genitourinary Group: Radical nephrectomy plus interferon-alfa-based immunotherapy compared with interferon alfa alone in metastatic renal-cell carcinoma: a randomised trial. Lancet. 2001; 358: 966-70.

5. Flanigan RC, Salmon SE, Blumenstein BA, Bearman SI, Roy V, McGrath PC, et al. Nephrectomy followed by interferon alfa-2b compared with interferon alfa-2b alone for metastatic renal-cell cancer. N Engl J Med. 2001; 345: 1655-9.

6. Flanigan RC, Mickisch G, Sylvester R, Tangen C, Van Poppel $\mathrm{H}$, Crawford ED. Cytoreductive nephrectomy in patients with metastatic renal cancer: a combined analysis. J Urol. 2004; 171: 1071-6.

7. Jeldres $\mathrm{C}$, Baillargeon-Gagne $\mathrm{S}$, Liberman $\mathrm{D}$, Isbarn $\mathrm{H}$, Capitanio U, Shariat SF, et al. A population-based analysis of the rate of cytoreductive nephrectomy for metastatic renal cell carcinoma in the United States. Urology. 2009; 74: 837-41.

8. Aben KK, Heskamp S, Janssen-Heijnen ML, Koldewijn EL, van Herpen CM, Kiemeney LA, et al. Better survival in patients with metastasised kidney cancer after nephrectomy: a populationbased study in the Netherlands. Eur J Cancer. 2011; 47: 2023-32.

9. Halbert RJ, Figlin RA, Atkins MB, Bernal M, Hutson TE, Uzzo $\mathrm{RG}$, et al. Treatment of patients with metastatic renal cell cancer: a RAND Appropriateness Panel. Cancer. 2006; 107: 2375-83.

10. Margulis V, Wood CG. Pre-surgical targeted molecular therapy in renal cell carcinoma. BJU Int. 2009; 103: 150-3.

11. Margulis V, Wood CG, Jonasch E, Matin SF. Current status of debulking nephrectomy in the era of tyrosine kinase inhibitors. Curr Oncol Rep. 2008; 10: 253-8.

12. Howlader N, Noone AM, Krapcho M, Garshell J, Neyman N, Altekruse SF, et al. SEER Cancer Statistics Review, 1975-2010, National Cancer Institute. Bethesda, MD, available at: http:// seer.cancer.gov/archive/csr/1975_2010/ based on November 2012 SEER data submission, posted to the SEER web site. 2013.

13. Escudier B, Eisen T, Stadler WM, Szczylik C, Oudard S, Siebels $M$, et al. Sorafenib in advanced clear-cell renal-cell carcinoma. N Engl J Med. 2007; 356: 125-34. Erratum in: N Engl J Med. 2007;357:203.
14. Snow G: Sensitivity analysis for Observational studies. Available at: http://cran.r-project.org/web/packages/obsSens/ obsSens.pdf

15. Crispen PL, Blute ML. Role of cytoreductive nephrectomy in the era of targeted therapy for renal cell carcinoma. Curr Urol Rep. 2012; 13: 38-46.

16. Choueiri TK, Xie W, Kollmannsberger C, North S, Knox JJ, Lampard JG, et al. The impact of cytoreductive nephrectomy on survival of patients with metastatic renal cell carcinoma receiving vascular endothelial growth factor targeted therapy. J Urol. 2011; 185: 60-6.

17. You D, Jeong IG, Ahn JH, Lee DH, Lee JL, Hong JH, et al. The value of cytoreductive nephrectomy for metastatic renal cell carcinoma in the era of targeted therapy. J Urol. 2011; 185: 54-9.

18. Kader AK, Tamboli P, Luongo T, Matin SF, Bell K, Jonasch E, et al. Cytoreductive nephrectomy in the elderly patient: the M. D. Anderson Cancer Center experience. J Urol. 2007; 177: 85560; discussion 860-1.

19. Kutikov A, Egleston BL, Canter D, Smaldone MC, Wong YN, Uzzo RG. Competing risks of death in patients with localized renal cell carcinoma: a comorbidity based model. J Urol. 2012; 188: $2077-83$.

20. Thomas K, David G, Christopher PE, Andrea T: Current and Future Trends in the Treatment of Renal Cancer. Eur urol suppl. 2007; 6: 374-84.

21. Motzer RJ, Hutson TE, Tomczak P, Michaelson MD, Bukowski RM, Rixe 0, et al. Sunitinib versus interferon alfa in metastatic renal-cell carcinoma. N Engl J Med. 2007; 356: 115-24.

22. Mekhail TM, Abou-Jawde RM, Boumerhi G, Malhi S, Wood L, Elson P, et al. Validation and extension of the Memorial SloanKettering prognostic factors model for survival in patients with previously untreated metastatic renal cell carcinoma. J Clin Oncol. 2005; 23: 832-41.

23. Lin DY, Psaty BM, Kronmal RA: Assessing the sensitivity of regression results to unmeasured confounders in observational studies. Biometrics. 1998; 54: 948-63.

24. Carmena. Randomized Phase III Trial Evaluating the Importance of Nephrectomy in Patients Presenting With Metastatic Renal Cell Carcinoma Treated With Sunitinib. Available at: https:// clinicaltrials.gov/ct2/show/NCT00930033?term=renal+cance r\&recr=0pen\&intr=nephrectomy\&rank=2. accessed in 2009.

Correspondence address: Ding-Wei Ye, MD Fudan University Shanghai Cancer Center No. 270 Dong'an Road Shanghai 200032, China. Fax: + 8621 6443-8640 E-mail: dwyeli@163.com 


\section{EDITORIAL COMMENT}

In this edition of Int Braz J Urol, Doe et al. describe an interesting retrospective analysis of the role of cytoreductive nephrectomy $(\mathrm{CN})$ in patients with metastatic renal cell carcinoma (mRCC) from the Surveillance, Epidemiology, and End Results (SEER) database. This is a widely researched and discussed topic in uro-oncology precisely because we have few (possibly none) high quality studies with level of evidence that can guide practice and help clinical management of such patients in the targeted therapy era.

The concept of cytoreduction is one of the pillars of modern surgical oncology and is applied in various types of neoplasms such as ovarian, colonic, bladder and more recently some groups have evaluated its role in prostate cancer $(1,2)$. In the mRCC scenario, two randomized phase III trials investigated the role of $\mathrm{CN}$ in the treatment of patients with mRCC during the immunotherapy era $(3,4)$. The combined analysis of such trials demonstrated a median survival of 13.6 months in the $\mathrm{CN}$ group versus 7.8 months in the systemic therapy-only group. The 31\% difference in risk of death was statistically significant $(p=0.002)$ favoring surgery (5). And this was considered the standard approach until the emergence of targeted therapy. Since then, the role of $\mathrm{CN}$ has been questioned.

Retrospective studies have confirmed the importance of $\mathrm{CN}$ in the targeted therapy era. However, unlike immunotherapy with interferon or IL-2, it is known that TKIs and mTOR inhibitors might present an objective response on the primary tumor too. That said, some key questions must be answered. Who deserves to undergo CN? What are the criteria used to select candidates for CN? When $\mathrm{CN}$ must be offered, prior or after systemic therapy? Is there any place for nephron-sparing surgery? Evidence suggests that patients at low or intermediate risk groups, with good performance status, low extrarenal tumor burden and no central nervous system metastasis are the ideal candidates to $\mathrm{CN}$ (6). The remaining issues remain unanswered.

The SURTIME trial (EORTC 30073, NCT01099423) and the CARMENA trial (NCT00930033) are currently investigating the utility of $\mathrm{CN}$ in the targeted therapy era and its ideal timing. Until preliminary results of such studies are published, the clinical management of mRCC patients will be based on extrapolations from the immunotherapy era; and despite all the limitations, from some interesting retrospective studies such as Doe et al. study.

\section{REFERENCES}

1. Al Rawahi T, Lopes AD, Bristow RE, Bryant A, Elattar A, Chattopadhyay $S$, et al. Surgical cytoreduction for recurrent epithelial ovarian cancer. Cochrane Database Syst Rev. 2013 Feb 28;2:CD008765.

2. Heidenreich A, Pfister D, Porres D. Radical cancer surgery of renal cell and prostate carcinoma with hematogenous metastasis: benefits. Urologe A. 2014;53:823-31.

3. Flanigan RC, Salmon SE, Blumenstein BA, Bearman SI, Roy $\mathrm{V}$, McGrath PC, et al. Nephrectomy followed by interferon alfa-2b compared with interferon alfa-2b alone for metastatic renal-cell cancer. N Engl J Med. 2001;345:1655-9.

4. Mickisch GH, Garin A, van Poppel H, de Prijck L, Sylvester $R$; European Organisation for Research and Treatment of Cancer (EORTC) Genitourinary Group. Radical nephrectomy plus interferon-alfa-based immunotherapy compared with interferon alfa alone in metastatic renal-cell carcinoma: a randomised trial. Lancet. 2001;358:966-70.

5. Flanigan RC, Mickisch G, Sylvester R, Tangen C, Van Poppel $\mathrm{H}$, Crawford ED. Cytoreductive nephrectomy in patients with metastatic renal cancer: a combined analysis. J Urol. 2004:171:1071-6.

6. Heng DY, Xie W, Regan MM, Warren MA, Golshayan AR, Sahi $C$, et al. Prognostic factors for overall survival in patients with metastatic renal cell carcinoma treated with vascular endothelial growth factor-targeted agents: results from a large, multicenter study. J Clin Oncol. 2009;27:5794-9.

Walter Henriques da Costa, MD AC Camargo Cancer Center, Urology E-mail: waltercosta@hotmail.com 